\title{
An Examination Of Traditional Business Case Studies - Are They Outdated In Today's Technology Connected Environment?
}

\author{
Roland J. Sparks, DBA, PE, Johnson \& Wales University, USA
} Jeri Langford, DBA, Johnson \& Wales University, USA

\begin{abstract}
The paper examines the effectiveness of using business case studies in today's Internet connected environment. The findings show that $87.8 \%$ of Harvard Business Review case solutions are commonly available on the Internet and that students can find an answer within 7.37 minutes. Based on this evidence, the authors contend that current use of business case studies as a learning tool requires a different approach. Standard case questions are no longer sufficient to ensure learning. Alternate approaches suggested are: students developing their own case analysis format, using local companies and data, the Real-Time Case Method, changing classifications and framing of cases, and contrasting case analysis.
\end{abstract}

Keywords: Case Analysis; Harvard Business Review; Alternate Case Analysis

\section{INTRODUCTION}

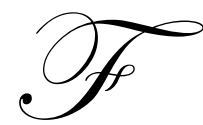

or college level business education, professors have relied on case studies to enhance student involvement and engagement to further theoretical understanding through hands-on practical analysis allowing students to address and understand the multiple aspects of business problems. (Lee, Lee, Liu, Bonk, \& Magjuka, 2009) Bloom's Taxonomy would say case studies help students remember previous subject matter, display understanding of the material, and apply current concepts to analyze and evaluate the case situation leading to creation of new ideas to solve the problem presented. (Overbaugh \& Schultz, 2011) However, professors have begun to wonder if case studies are still an effective learning tool as they were in the past or has case study analysis been corrupted by the easily available information now on the Internet?

The history of case studies dates back to the first writings in education. Scholars would cite specific experiences and develop packets of information they would share with students. Students would review the material, probably working in groups, and analyze the case based on past experiences. Through detailed analysis and repeated exposure, students would incorporate past learning to help develop solutions to the problem at hand. With guidance from the instructor, the student would clarify and defend their solution as the optimal answer to the case study thus progressing through the six levels of learning in the Bloom's Taxonomy model.

Case study analysis is shown to: improve job performance (Iqbal, Shaikh, \& Nazar, 2010); be effective in online learning (Lee, Lee, Liu, Bonk, \& Magjuka, 2009); help students understand theory (Collinson \& Rugman, 2011; Johnson \& Helms, 2008); integrate multiple issues to increase comprehension (Taucean \& Tamasila, 2009; Rippin, Booth, Bowie, \& Jordan, 2002); increase student interest in learning (Johnson \& Helms, 2008); increase student motivation to learn (Moore, 2010); and improve cognitive learning (Schwartz \& Bransford, 1999). Literature indicates case study analysis improved student performance in: business statistics (Pariseau \& Kezim, 2007); sports marketing (Sanchis, 2007); business law (Sipe, 2007); strategic management (Okumus, Wong, \& Altinay, 2008); accounting (Colignon \& Covaleski, 1993); and strategic marketing (Wu, Tang, \& Shyu, 2010). 
The effectiveness of case study analysis assumes that students do not already know the answers to the case questions. Moreover, the answer requires some effort to obtain through the synthesis of various subject areas by the student. In short, learning is directly related to the effort and time the student spends in the research and analysis.

The majority of case studies are now written and published by various third party contributors such as the Harvard Business School or various textbook publishers. Cases are provided to the professor with sample questions and solutions to help guide instructors to the key areas of the case. This ease of use made case analysis more popular in the classroom.

Various college instructors have gathered anecdotal evidence that more and more students now turn to the Internet to find the answers to case study questions without even reading the case or developing solutions on their own. However, there have been no detailed studies to assess the extent of this problem or how easily the case solutions can be found by students over the Internet.

\section{METHODOLOGY}

This paper looks to examine and describe the ease which students can get case solutions over the Internet and the quality of these answers. Forty-two first term freshman students were randomly selected and given one of nine randomly selected Harvard Business Review Case studies. ${ }^{1}$ The student was only given the first page of the case study and the questions. This prevented the student from reading the full case. The student was given a computer with Internet access and asked to find the answers to these questions based on the information given. Each student was allotted a max time of two hours but could leave once the assignment was completed. Students recorded their work, time to get answers and website resources used. Each case study had a minimum of three separate students perform the questions analysis.

\section{RESULTS}

The results for each case analysis are listed in the Table 1. Only the best student answers were included in the table since this study was about information available on the Internet and not a comparison of student's ability or efforts on a non-graded assignment.

Table 1

Summary of Case Solution Found on the Internet

\begin{tabular}{|l|c|c|c|c|c|c|}
\hline \multicolumn{1}{|c|}{ Case } & Year & $\begin{array}{c}\text { \# of Case } \\
\text { Questions }\end{array}$ & $\begin{array}{c}\text { \# Case } \\
\text { Questions } \\
\text { Answered } \\
\text { Correctly }\end{array}$ & $\begin{array}{c}\text { Percentage } \\
\text { of Correct } \\
\text { Case } \\
\text { Answers }\end{array}$ & $\begin{array}{c}\text { Time to } \\
\text { Answer } \\
\text { All Case } \\
\text { Questions } \\
\text { (Minutes) }\end{array}$ & $\begin{array}{c}\text { Average Time } \\
\text { To Answer } \\
\text { Question } \\
\text { Correctly } \\
\text { (Minutes) }\end{array}$ \\
\hline Porsche: The Cayenne Launch & 2011 & 5 & 4 & $80.0 \%$ & 26 & 6.5 \\
\hline $\begin{array}{l}\text { Reliance Baking Soda: Optimizing } \\
\text { Promotional Spending }\end{array}$ & 2009 & 4 & 3 & $75.0 \%$ & 20 & 6.6 \\
\hline Salty Snacks & 2010 & 8 & 8 & $100 \%$ & 20 & 2.5 \\
\hline Dove: Evolution of a Brand & 2008 & 5 & 5 & $100 \%$ & 30 & 6.0 \\
\hline $\begin{array}{l}\text { MedNet.com Confronts "Click- } \\
\text { Through" Competition }\end{array}$ & 2007 & 5 & 5 & $100 \%$ & 20 & 4.0 \\
\hline Online Marketing at Big Skinny & 2011 & 4 & 2 & $50.0 \%$ & 40 & 20.0 \\
\hline IKEA Invades America & 2004 & 7 & 6 & $85.7 \%$ & 45 & 7.5 \\
\hline Prediction Markets at Google & 2007 & 5 & 5 & $100 \%$ & 40 & 8.0 \\
\hline $\begin{array}{l}\text { The Black \& Decker Corporation } \\
\text { (A): Power Tools Division }\end{array}$ & 2001 & 4 & 4 & $100 \%$ & 21 & 5.3 \\
\hline Averages & & $\mathbf{5 . 2}$ & $\mathbf{4 . 7}$ & $\mathbf{8 7 . 8 \%}$ & $\mathbf{2 7 . 1}$ & \\
\hline
\end{tabular}

${ }^{1}$ The nine HBR case studies used are: The Black \& Decker Corporation (A): Power Tools Division (2001); Dove: Evolution of a Brand (2008); IKEA Invades America (2004); Online Marketing at Big Skinny (2011); Porsche: The Cayenne Launch (2011); Prediction Markets at Google (2007); MedNet.com Confronts "Click-Through" Competition (2007); Reliance Baking Soda: Optimizing Promotional Spending (2009); and Salty Snacks (2010). 
The sample indicates that students can find case solutions online from free and easy to access websites on the Internet. The average time to find case solutions on the Internet was 27.1 minutes with an $87.8 \%$ accuracy rate. This is an average of 7.4 minutes per case question. This is far from 10-15 hours which is normally required to fully analyze an HBR case study. In addition, there is no correlation between how new a case is and the solutions availability.

An analysis of resources used by the students in their research is shown in Table 2.

Table 2

Summary of Most Useful Websites to Find Case Solutions

\begin{tabular}{|c|c|c|c|}
\hline $\begin{array}{l}\text { Number of } \\
\text { Answers } \\
\text { Found }\end{array}$ & Type of Site & $\begin{array}{c}\text { Information Available on } \\
\text { Site }\end{array}$ & Sample Site Address \\
\hline 99 & $\begin{array}{l}\text { Individual blog sites. These sites are open to } \\
\text { the public. They allow anyone to set up an } \\
\text { individual web address and post any type of } \\
\text { information. }\end{array}$ & Entire case study solutions. & $\begin{array}{l}\text { username.blogspot.com } \\
\text { username.wordpress.com } \\
\text { www.scribd.com } \\
\text { www.slideshare.net }\end{array}$ \\
\hline 9 & $\begin{array}{l}\text { Professional sites. Some required creating an } \\
\text { accounting or paying a minimal fee to } \\
\text { access. }\end{array}$ & Entire case study solutions. & $\begin{array}{l}\text { www.oppapers.com } \\
\underline{\text { www.papercamp.com }}\end{array}$ \\
\hline 14 & $\begin{array}{l}\text { Educational (.edu) sites. Individual student } \\
\text { sites located within the university system. }\end{array}$ & $\begin{array}{l}\text { Answers to selected } \\
\text { questions to entire case } \\
\text { solutions. }\end{array}$ & $\begin{array}{l}\text { www.tku.edu } \\
\underline{\text { smgapps.bu.edu }}\end{array}$ \\
\hline 13 & $\begin{array}{l}\text { Company or trade sites. Individual corporate } \\
\text { or trade organization sites that referenced the } \\
\text { same cases on their websites. }\end{array}$ & $\begin{array}{l}\text { Answers to selected } \\
\text { questions. }\end{array}$ & $\begin{array}{l}\text { www.midasoracle.org } \\
\text { www.itbusinessedge.com } \\
\text { www.wetpaint.com }\end{array}$ \\
\hline 7 & $\begin{array}{l}\text { Answer sites. Sites where one can post a } \\
\text { question and people answer the questions. } \\
\text { Much like a discussion board. }\end{array}$ & $\begin{array}{l}\text { Answers to selected } \\
\text { questions. }\end{array}$ & $\begin{array}{l}\text { www.123helpme.com } \\
\text { answers.yahoo.com } \\
\text { wiki.answers.com }\end{array}$ \\
\hline
\end{tabular}

Table 2 indicates that most solutions are posted by individuals using publicly available blog areas. These areas are commonly indexed through search engines like Google allowing students to find this information easily. Moreover, these websites seem to be unmonitored allowing individuals to commonly publish copyrighted material. The worst offenders are blogspot.com with 41 solutions found and wordpress.com with 25 solutions posted.

Scribd.com represents itself as an online website that allowed authors to self-publish their original work. However, this website was referenced 32 times by students. Reviews of the website indicated entire case solutions were posted by these so called self-publishing authors. It appears that these self-publishing sites have little oversight or review processes.

Two professional websites that sell full solutions were www.oppapers.com (7 references) and www.papercamp.com (2 references). Oppapers.com is registered by go.daddy.com through its subsidiary Domains by Proxy, Inc. which is a way individuals can register a domain and remain anonymous. Papercamp.com is part of oppapers.com. Both advertise as a great way to improve student grades by offering over 500,000 essays online to anyone willing to pay membership rates. In addition, companies can advertise on these sites. Firms such as Verizon Wireless, UPS and Progressive are advertisers on these sites.

\section{Anecdotal Observations during the testing period.}

During the research period an instructor observed the students in their efforts. Several interesting items were observed:

- $\quad$ The fastest student was done in 20 minutes and had all eight case questions answered correctly. 
- $\quad$ There were about $20 \%$ of students that did not have any success in finding solutions online. The instructor allowed students to interact with students working on different cases. Within five minutes of instruction from other students, the students who did not have success on the assignment were able to find the solutions for their case. Student interaction was a great teaching tool for finding helpful websites.

- $\quad$ Many sites had the full case study and solutions posted.

- $\quad$ Some sites had some of the correct solutions posted and required a fee of between $\$ 2-\$ 7$ for the remaining solutions.

- $\quad$ Three of the 42 students were led to sites with Trojan viruses.

\section{CONCLUSION}

The traditional use of case studies using predefined questions is obsolete due to easily available solutions online. Roughly $80 \%$ of entering freshmen college students already have the ability to circumvent the case study process by using online resources. The other $20 \%$ can learn these skills in under five minutes. Based on anecdotal evidence from current university faculty the same concerns apply to textbook cases as well as HBR cases. In short, no case is left unanswered and all students have to do is go online and find the solutions. And the average student takes less than one-half hour to do so. Even if the solution is not posted, one can post these questions to one of the many sites online in hopes someone will answer the question for them.

Even with these concerns, the case study is still a key learning tool. Although no one has studied how to avoid the online resource pitfall there were five techniques found in the literature that may be useful in saving the case study method. The techniques are: Student Developed Case Analysis Format (Menna, 2010); the use of local companies with time sensitive data (Johnson \& Helms, 2008); the Real-Time Case Method (Kilbane, et al., 2004; Theroux \& Kilbane, 2004); the Classifications and Framing Method (Badger, 2010); and the Contrasting Case Method (Schwartz \& Bransford, 1999). Further research in this area is needed to determine if any of these alternate case analysis methods overcomes the online resource problem.

\section{AUTHOR INFORMATION}

Roland Sparks is an associate professor of business at Johnson \& Wales University. His specialties are in various uses of technology in business and education. Sparks spent 15 years in business before switching careers to become a university professor. Sparks holds degrees in D.B.A International Business, MS International Business, MBA, and BS Physics. Sparks is a Certified Public Manager and Professional Engineer. E-mail: roland.sparks@jwu.edu. Corresponding author.

Jeri Langford has more than 20 years international corporate experience. Her background includes sales and marketing positions with IBM, Belk, AT\&T and BellSouth. From Account Executive to Product Marketing Management to Technical Designer, Jeri presents a unique teaching style that addresses both the right-brain and leftbrain thinkers. Previous to Johnson \& Wales University she has been a faculty member at Montreat College, National American University and Pfeiffer University teaching advertising, consumer behavior, information technology, management, and marketing courses. She holds a North Carolina Real Estate Broker's license and is a certified Advanced Technical Instructor. Langford's education is a D.B.A., MBA and BS in Business. E-mail: jeri.langford@jwu.edu

\section{REFERENCES}

1. Badger, J. (2010, November). Classification and framing in the case method: discussion leaders' questions. Journal of Further \& Higher Education, 34(4), 503-518.

2. Coles, P. A., Lakhani, K. R., \& Mcafee, A. P. (2007, August 20). Prediction Markets at Google. Case Study. Harvard Business Publishing for Educators.

3. Colignon, R. A., \& Covaleski, M. (1993, March). Accounting Practices and Organizational Decision Making. Sociological Quarterly, 34(2), 299-317.

4. Collinson, S. C., \& Rugman, A. M. (2011, January-March). Relevance and Rigor in International Business Teaching: Using the CSA-FSA Matrix. Journal of Teaching in International Business, 22(1), 29-37. 
5. Dawes, J. (2010). Salty Snacks. Case Study. Harvard Business Publishing for Educators.

6. Deighton, J. (2008, March 25). Dove: Evolution of a Brand. Case Study. Harvard Business Publishing for Educators.

7. Deighton, J., Avery, J., \& Fear, J. (2011, March 29). Porsche: The Cayenne Launch. Case Study. Harvard Business Publishing for Educators.

8. Dolan, R. J. (2001, March 30). The Black \& Decker Corporation (A): Power Tools Division. Case Study. Harvard Business Publishing for Educators.

9. Edelman, B., \& Kominers, S. D. (2011, February 8). Online Marketing at Big Skinny. Case Study. Harvard Business Publishing for Educators.

10. Iqbal, M. S., Shaikh, F. M., \& Nazar, M. (2010, October). Impact of the Case Study Method on the Job Performance of Business Graduates: A Case Study of Institute of Business Administration Sukhur. Asian Social Science, 6(10), 193-200.

11. Johnson, L. A., \& Helms, M. M. (2008, May). Keeping it local: Incorporating a local case study in the business curriculum. Education + Training, 50(4), 315-328.

12. Kilbane, C., Theroux, J., Sulej, J., Bisson, B., Hay, D., \& Boyer, D. (2004, Winter). The Real-Time Case Method: Description and Analysis of the First Implementation. Innovative Higher Education, 29(2), 121 135.

13. Lee, S.-h., Lee, J., Liu, Z., Bonk, C. J., \& Magjuka, R. J. (2009, July). A review of case-based learning practices in an online MBA program: A program-level case study. Journal of Educational Technology \& Society, 12(3), 178-190.

14. Markulis, P. M., Howe, H., \& Strang, D. R. (2005, June). Integrating the business curriculum with a comprehensive case study: A prototype. Simulation \& Gaming, 36(2), 250-258.

15. Menna, A. (2010, April). The business case method: an examination of a 2009 case competition. Management in Education, 24(2), 74-79.

16. Mook, Y. (2004, September 14). IKEA Invades America. Case Study. Harvard Business Publishing for Educators.

17. Moore, K. N. (2010, July-September). Development Through Business: What Do American Business Students Know About Emerging Markets and Opportunities in Africa? Journal of Teaching in International Business, 21(3), 200-219.

18. Okumus, F., Wong, K. K., \& Altinay, L. (2008). Are We Teaching Strategic Management Right? Journal of Teaching in Travel \& Tourism, 8(4), 329-350.

19. Overbaugh, R. C., \& Schultz, L. (2011). Bloom's Taxonomy. Retrieved October 12, 2011, from www.odu.edu:http://www.odu.edu/educ/roverbau/Bloom/blooms_taxonomy.htm

20. Pariseau, S. E., \& Kezim, B. (2007, September/October). The Effect of Using Case Studies in Business Statistics. Journal of Education for Business, 83(1), 27-31.

21. Persky, A. M. (2011, August 30). What the research tells us about learning: what might we be overlooking? Presentation for the Faculty In-Service at Johnson \& Wales University. Charlotte, NC.

22. Quelch, J. A., \& Beckham, H. (2009, December 20). Reliance Baking Soda: Optimizing Promotional Spending. Case Study. Harvard Business Publishing for Educators.

23. Rippin, A., Booth, C., Bowie, S., \& Jordan, J. (2002, October). A Complex Case: using the case study method to explore uncertainty and ambiguity in undergraduate business. Teaching in Higher Education, 7(4), 429-441.

24. Sanchis, C. M. (2007, October). The case study method: a powerful teaching tool in sports marketing education. Journal of Sports Marketing \& Sponsorship, 9(1), 7-10.

25. Schwartz, D. L., \& Bransford, J. D. (1999). A Time for Telling. Cognition and Instruction, $475-522$.

26. Sipe, S. R. (2007, September). Maximizing Student Learning Through Enron: The Ultimate B-Law Case Study. Journal of Legal Studies Education, 24(2), 325-337.

27. Taucean, 1. M., \& Tamasila, M. (2009). Case Studies Correlation Analysis for Business Management Teaching. Annals of DAAAM \& Proceedings, (pp. 209-210).

28. Theroux, J., \& Kilbane, C. (2004, Jan/Feb). The Real-Time Case Method: A New Approach to an Old Tradition. Journal of Education for Business, 79(3), 163-167.

29. Wu, H.-H., Tang, Y.-T., \& Shyu, J.-W. (2010, October). A case of applying importance-performance analysis in identifying key success factors to develop marketing strategies. Quality \& Quantity, 44(6), 1207-1218. 
30. Young, A. (2007, April 20). MedNet.com Confronts "Click-Through" Competition. Case Study. Harvard Business Publishing for Educators.

\section{NOTES}

